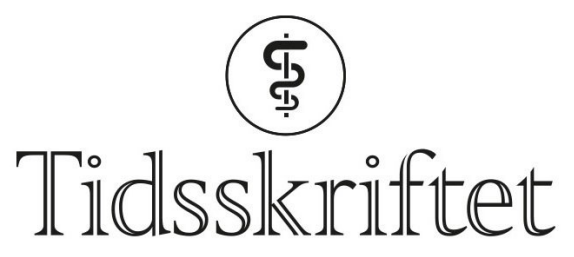

DEN NORSKE LEGEFORENING

\title{
Ebolavirusinfeksjon uten symptomer er sjeldent
}

FRA ANDRE TIDSSKRIFTER

KRISTOFFER BRODWALL

E-post: kristoffer.brodwall@gmail.com

Barne- og ungdomsklinikken

Haukeland universitetssykehus

Asymptomatisk infeksjon med ebolavirus forekommer sjelden, viser ny studie. Derfor er det lite sannsynlig at asymptomatiske bærere bidrar til sykdomsspredning.

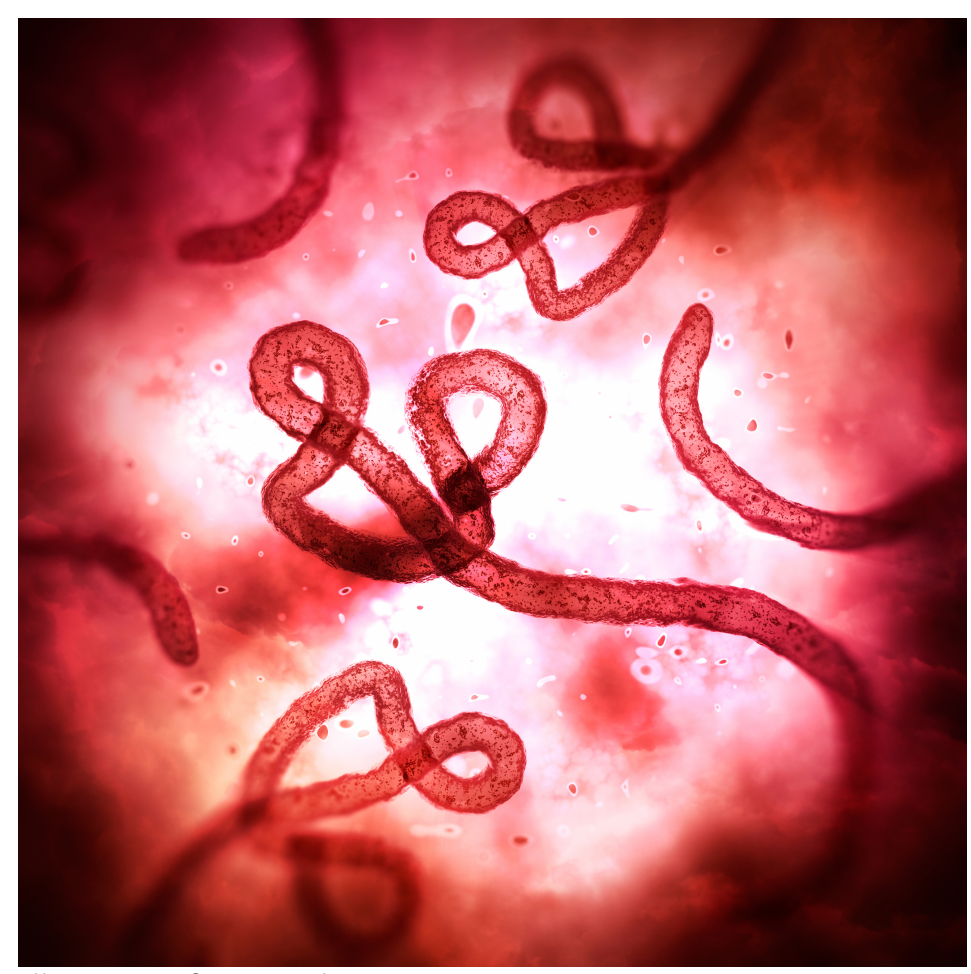

Illustrasjonsfoto: iStock

I 2014-15 var det et stort ebolautbrudd i Vest-Afrika med over 28 ooo syke mennesker (1). Ebolavirusets naturlige reservoar er ukjent, noe som gjør det vanskelig å forutsi og forebygge nye utbrudd. Enkelte eldre studier har antydet at asymptomatiske infeksjoner er vanlig, og noen eksperter har derfor fryktet at asymptomatiske bærere kan bidra til spredning av sykdommen. I en ny studie fra Sierra Leone kartlegges forekomsten av asymptomatiske ebolavirusinfeksjoner (2). Forfatterne validerte først en ny diagnostisk metode, ved å teste spytt for spesifikt IgG mot ebolavirus. Prøven var positiv for $93 \mathrm{av}$ 
97 personer som hadde overlevd PCR-bekreftet ebolavirusinfeksjon (sensitivitet 95,9\%) og negativ for alle 339 kontrollpersonene (spesifisitet 100\%).

Spyttprøven ble deretter brukt til å teste smitteutsatte personer fra samme husstand som personer med påvist ebolavirusinfeksjon. Ingen av disse personene hadde selv fått diagnostisert ebolavirusinfeksjon, men omtrent en femdel av dem hadde hatt ulike symptomer. Spyttprøven var positiv hos 10 av 388 personer uten symptomer $(2,6 \%)$ og hos 11 av de 92 personene med symptomer (12,0\%). Blant de asymptomatiske var positiv prøve svak korrelert med grad av smitteeksponering.

Resultatene tyder på at asymptomatiske ebolavirusinfeksjoner forekommer sjelden, selv hos personer som har vært eksponert for ebolasyke. Forfatterne konkluderer med at smittespredning i liten grad skjer gjennom asymptomatiske bærere og at asymptomatiske infeksjoner i liten grad gir flokkimmunitet mot ebolavirus. Spyttprøven som ble brukt i studien kan forenkle massetesting ved senere ebolautbrudd.

LITTERATUR:

1. Kuhn JH, Bavari S. Asymptomatic Ebola virus infections-myth or reality? Lancet Infect Dis 2017; 17: 570 - 1. [PubMed][CrossRef]

2. Glynn JR, Bower H, Johnson S et al. Asymptomatic infection and unrecognised Ebola virus disease in Ebola-affected households in Sierra Leone: a cross-sectional study using a new non-invasive assay for antibodies to Ebola virus. Lancet Infect Dis 2017; 17: 645 - 53. [PubMed][CrossRef]

Publisert: 21. august 2017. Tidsskr Nor Legeforen. DOI: 10.4045/tidsskr.17.0528

(C) Tidsskrift for Den norske legeforening 2020. Lastet ned fra tidsskriftet.no 